\title{
PEMBELAJARAN SAINTIFIK DALAM PENINGKATAN MOTIVASI BELAJAR PAI DI SMK NEGERI MOJOAGUNG JOMBANG
}

\author{
Abd. Rozaq \\ abdrozaq1890@gmail.com \\ STIT Al-Urwatul Wutsqo - Jombang \\ Umi Habibah \\ umihabibah892@gmail.com \\ STIT Al-Urwatul Wutsqo - Jombang
}

\begin{abstract}
This study describes the application of scientific learning in Islamic education subjects at SMK Negeri Mojoagung. This research uses a qualitative approach. Data collection methods: observation, interviews and documentation. The data analysis technique uses the interactive model of Miles and Huberman which includes data reduction, data presentation and conclusion drawing. To check the validity of the data, it was used research extension, observation persistence and triangulation. The result of the research is that scientific learning in Islamic Education subjects at SMK N Mojoagung is applied through student learning activities as follows: Observing (seeing pictures, reading, listening to and identifying the reading of the Koran, listening to explanations, observing the benefits and lessons of wisdom), asking questions (teacher asking students, students asking the teacher, students asking students), trying (memorizing the arguments of the Qur'an, looking for benefits and wisdom, digging information about the consequences of an action, looking for arguments from the Al-Qur'an or hadith from other sources), reasoning (making conclusions about the benefits and wisdom of orders or prohibitions, making conclusions on matters relating to the impact of doing an action), communicating (expressing opinions, presenting the results of conclusions orally or in writing and responding to a friend's presentation).
\end{abstract}

Keyword: Scientific Learning, Learning Motivation.

\section{Pendahuluan}

Peran Pendidikan dalam kemajuan bangsa adalah sebagai sarana untuk membangun dan membentuk karakter bangsa. Sehingga jika masyarakat suatu bangsa memiliki kecerdasan yang tinggi maka akan menimbulkan suasana dan nuansa kehidupan cerdas pula, begitupun juga sebaliknya. ${ }^{1}$ Dalam

\footnotetext{
${ }^{1}$ Moch. Sya'roni Hasan dan Dian Eka Saputri. 2020. “Pembelajaran PAI Berbasis Moving Class Di SMP Negeri 1 Gudo Jombang". Attaqwa: Jurnal Ilmu Pendidikan Islam 16 (2):113-25. https://doi.org/10.36835/attaqwa.v16i2.47.
} 
pelaksaannya kurikulum menjadi bagian penting dalam keberhasilan pendidikan. Kurikulum merupakan hal yang terpenting dalam pelaksanaan pembelajaran. Bahkan tidak ada gunanya sebuah kurikulum jika tidak diaplikasikan dalam pembelajaran. ${ }^{2}$ Oleh karena itu, seorang guru menjadi bagian terpenting dalam sukses atau tidaknya dalam pelaksanaan kurikulum. Guru diharapkan mampu mendesain sebuah pembelajaran yang mudah dan menyenangkan. ${ }^{3}$

Pada pelaksanaan kurikulum 2013 guru harus menggunakan pendekatan saintifik dalam proses belajar mengajar di kelas. ${ }^{4}$ Pendekatan saintifik bisa dilakukan dengan beberapa langkah antara lain menanya. mengamati, menalar, mencoba dan mengembangkan jaringan. ${ }^{5}$ Dengan pendekatan saintifik ini diharapkan siswa mendapat pengetahun dan nilai yang bermakna selama proses pembelajaran yang bisa diterapkan dalam kehidupan sehari-hari.

Dalam pelaksanaan kurikulum K-13, guru PAI harus menyadari bahwa aktifitas belajar yang dilakukan oleh siswa sangat memerlukan motivasi dari luar. Oleh karena itu, guru harus berupaya agar siswa termotivasi ketika mengikuti proses belajar mengajar di kelas. Guru PAI juga diharapkan untuk memikirkan bagaimana caranya materi pelajaran bisa disampaikan ke siswa tetapi tidak membuat mereka jenuh, malas dan lain sebagainya. ${ }^{6}$ Sangat penting sekali untuk membuat siswa termotivasi dalam belajar. Motivasi belajar merupakan dorongan yang ada dalam diri siswa untuk melakukan proses belajar yang lebih dari biasanya. Dorongan itu bisa datang dalam diri siswa maupun dari luar. ${ }^{7}$

Pembelajaran dengan pendekatan saintifik dalam implementasi Kurikulum 2013 menyajikan model, strategi, dan metode mengajar yang bervariasi, menciptakan aktifitas belajar yang beragam sehingga memungkinkan siswa terlibat secara penuh dalam kegiatan belajar di kelas. Dengan adanya inovasi pembelajaran tersebut diharapkan mampu menumbuhkan dan meningkatkan motivasi belajar siswa terhadap semua mata pelajaran yang diajarkan di sekolah, termasuk mata pelajaran PAI yang sekarang berubah nama menjadi Pendidikan Agama Islam dan Budi pekerti.

2 Sholeh Hidayat, Pengembangan Kurikulum Baru (Bandung: Remaja Rosda Karya, 2013), 157

3 E. Mulyasa, Pengembangan dan Implementasi Kurikulum 2013 (Bandung: Remaja Rosda Karya, 2015), 99.

${ }^{4}$ Muhammad Fathurrahman, Paradigma Pembelajaran Kurikulum 2013 (Yogyakarta: Kalimedia, 2015), 108.

${ }^{5}$ Ridwan Abdulloh Sani, Pembelajaran Saintifik untuk Implementasi Kurikulum 2013 (Jakarta: Bumi Aksara, 2014), 2.

${ }^{6}$ Mulyasa, Pengembangan, 107.

7 Jamaludin , Pembelajaran, 60. 
Namun selama ini, peran mata pelajaran agama yang signifikan tersingkirkan dengan rendahnya antusiasme para peserta didik. Rendahnya motivasi siswa (khususnya sekolah umum) terhadap mata pelajaran agama, sering dikait-kaitkan dengan proses pembelajarannya yang kurang menarik, monoton serta muatan materi yang sulit dipahami. ${ }^{8}$ Kini kurikulum 2013 telah banyak di implementasikan di sekolah-sekolah baik swasta maupun negeri, artinya proses pembelajaran sudah banyak yang menggunakan pendekatan pembelajaran saintifik.

Sekolah Menengah Kejuruan Negeri Mojoagung adalah salah satu sekolah unggulan yang melaksanakan implementasi Kurikulum 2013. Seperti yang telah dituturkan oleh Ibu Tutik Roikanah selaku guru PAI SMK Negeri Mojoagung ketika diwawancarai peneliti pada kegiatan Praktek Pengalaman Lapangan, “Kurikulum yang dipakai di sekolah ini adalah Kurikulum 2013. Sekolah ini telah menerapkan kurikulum 2013 sejak pertama kali diberlakukan perubahan kurikulum dan merupakan salah satu sekolah yang terpilih sebagai pilot projek pemerintah di kota Jombang" ${ }^{9}$

Penerapan Kurikulum 2013 pada SMK Negeri Mojoagung sudah berjalan 4 tahun, waktu yang bisa dikatakan cukup untuk bisa melihat bagaimana keberhasilan implementasi Kurikulum 2013 khususnya dari segi proses pembelajarannya. Di sekolah ini, hampir semua guru melakukan proses pembelajaran dengan menggunakan pembelajaran saintifik, tidak terkecuali guru PAI.

Berkaitan dengan ini, peneliti merasa tertarik menjadikan SMK Negeri Mojoagung untuk dijadikan lokasi penelitian. Dalam hal ini, peneliti ingin mengetahui penerapan pembelajaran saintifik pada mata pelajaran Pendidikan Agama Islam dan Budi Pekerti, motivasi belajar siswa pada mata pelajaran Pendidikan Agama Islam dan Budi Pekerti, keefektifan pembelajaran saintifik dalam peningkatan motivasi belajar Pendidikan Agama Islam dan Budi Pekerti, sekaligus faktor yang menjadi pendukung dan penghambatnya.

\section{Kajian Pustaka.}

\section{Pembelajaran Saintifik.}

Pembelajaran adalah proses ilmiah, karena sifatnya mencari kebenaran yang universal. Maka dari itu, pendekatan yang digunakan dalam pembelajaran

\footnotetext{
${ }^{8}$ Moch. Sya'roni Hasan, 2019. "INTERNALISASI NILAI TOLERANSI BERAGAMA". DAR EL-ILMI : Jurnal Studi Keagamaan, Pendidikan Dan Humaniora 6 (1), 79-111. http://ejurnal.unisda.ac.id/index.php/dar/article/view/1469.

${ }^{9}$ Hasil wawancara dengan Ibu Hj. Tutik Roikanah, M. Pd.I, Guru PAI di SMPN Mojoagung Jombang, 30 Oktober 2017.
} 
kurikulum 2013 adalah pendekatan ilmiah (saintifik). ${ }^{10}$ Pembelajaran saintifik merupakan pembelajaran yang berpusat pada siswa, dimana siswa dituntut untuk menemukan sendiri materi yang berkaitan dengan mata pelajaran tertentu. ${ }^{11}$ Pembelajaran ini menuntut siswa mampu beraktivitas sebagaimana seorang ahli sains. Praktiknya siswa di haruskan melakukan serangkaian aktivitas selayaknya langkah langkah penerapan metode ilmiah. ${ }^{12}$

\section{Aktivitas Pembelajaran Saintifik}

\section{a. Mengamati/observasi}

Proses mengamati dalam pembelajaran saintifik bertujuan untuk memberi kesempatan kepada siswa agar mengungkapkan rasa ingin tahunya pada proses belajar mengajar. Selain itu, belajar dengan cara mengamati menjadikan apa yang diterima oleh siswa ketika proses belajar mengajar lebih tertanam dalam akal pikiran mereka. Dari proses mengamati dalam membentuk kompetensi seperti teliti, hati-hato, sunguhsungguh dan berusaha mencari informasi.13 Aktivitas belajar ketika mengamati antara lain: melihat, mengamati, membaca, mendengar, menyimak (tanpa dan dengan alat). ${ }^{14}$

\section{b. Menanya}

Menanya dalam pendekatan saintific merupakan proses mengajukan pertanyaan tentang segala sesuatu tentang apa yeng belum dipahami dari apa yang telah diamati atau dalam rangka menambah pengetahuan dari apa yang belum didapat dari proses pengamatan. ${ }^{15}$ Dari pertanyaan yang bersifat konkrit sampai ke abstrak, yang berkenaan dengan fakta, konsep, ataupun prosedural. 16

Kegiatan menanya ini dapat membentuk kompetensi antara lain menjadikan anak kreatif, berfikir kritis, selalu belajar dari setiap kejadian dan memupuk rasa ingin tahu siswa. Keterampilan menanya tidak bisa muncul dengan sendirinya. Akan tetapi harus dilatih dan ada bimbingan dari seorang guru.

\section{c. Mencoba/eksperimen}

Belajar dengan menggunakan pendekatan ilmiah akan melibatkan siswa dalam melakukan aktivitas menyelidiki fenomena dalam upaya menjawab

\footnotetext{
10 Fadlillah, Implementasi, 175.

11 Fathurrahman, Paradigma, 115.

12 Yunus Abidin, Desain Sistem Pembelajaran dalam Konteks Kurikulum 2013 (Bandung: Refika Aditama, 2014), 125.

13 Daryanto, Pendekatan, 61.

14 Fathurrahman, Paradigma, 121.

15 Daryanto, Pendekatan, 65.

16 Abidin, Desain, 137.
} 
pertanyaan. Hal ini dilakukan agar siswa memperoleh hasil belajar yang nyata atau konkrit. Kegiatan ini dimulai dari menggali dan mengumpulkan informasi dari berbagai sumber melalui berbagai cara. ${ }^{17}$

Informasi tersebut menjadi dasar bagi kegiatan berikutnya, yaitu memproses informasi untuk menemukan keterkaitan satu informasi dengan informasi lainnya, menemukan pola dari keterkaitan informasi dan bahkan mengambil berbagai kesimpulan dari pola yang ditemukan. ${ }^{18}$

\section{d. Menalar/mengasosiasikan}

Kegiatan menalar dalam pendekatan saintifik merupakan kegiatan berfikir dan menarik kesimpulan berdasarkan data atau informasi yang telag didapat dari proses menanya, mengamati dan mencoba. ${ }^{19}$ Kegiatan menalar adalah proses berfikir yang logis dan sistematis atas fakta-fakta empiris yang dapat di observasi untuk memperoleh simpulan berupa pengetahuan. proses mengasosiasi meliputi kegiatan menganalisis data dalam bentuk membuat kategori atau menentukan hubungan data/ kategori kemudian menyimpulkan dari hasil analisis data. ${ }^{20}$

\section{e. Mengomunikasikan}

Kegiatan berikutnya adalah menuliskan atau menceritakan apa yang ditemukan dalam kegiatan mencari informasi, mengasosiasikan, dan menemukan pola. ${ }^{21}$ Dalam kegiatan ini, menuntut adanya kemampuan siswa dalam menyampaikan hasil kegiatan yang sudah dilaksanakan secara lisan maupuan tulisan. Dalam hal ini, siswa harus mampu menulis dan berbicara secara komunikatif dan efektif. ${ }^{22}$

\section{Motivasi Belajar}

Dalam kegiatan belajar, motivasi dapat diartikan sebagai sesuatu yang menggerakkan atau mendorong siswa untuk belajar atau menguasai materi pelajaran yang diikutinya. Keseluruhan daya penggerak dalam diri siswa itu akan menimbulkan, menjamin kelangsungan, dan memberikan arah kegiatan belajar, sehingga diharapkan tujuan yang ada dapat tercapai. Motivasi belajar sangat diperlukan, karena seseorang yang tidak mempunyai motivasi dalam belajar, tidak akan mungkin bisa melakukan aktivitas belajar. Sebaliknya, aktifitas belajar yang meliputi berbagai macam perbuatan mulai dari mengamati, membaca, menurun, mencoba sampai mendengar, akan mudah

\footnotetext{
17 Fathurrahman, Paradigma, 137.

18 Fadlillah, Implementasi,185.

19 Sani, Pembelajaran, 66

${ }^{20}$ Fathurrahman, Paradigma, 140.

21 Fadlillah, Implementasi, 185.

22 Abidin, Desain, 141.
} 
dilakukan apabila dalam diri siswa sudah memiliki motivasi. ${ }^{23}$

\section{Indikator Motivasi Belajar}

Derajat motivasi belajar anak dapat diamati dari perilaku belajar anak dikelas. Menurut Worrell dan Stilwell yang dikutip Jamaluddin, ada 3 aspek perilaku belajar siswa yang memperlihatkan adanya motivasi positif dalam belajarnya.

Pertama, adanya inisiasi aktivitas belajar anak, yang diperlihatkan oleh perilaku anak dengan indikator sebagai berikut: anak menunjukkan minat dan keingintahuan yang tinggi, tingginya perhatian anak terhadap pembelajaran yang disajikan, mempunyai dorongan yang kuat untuk menyelesaikan sejumlah tugas dari guru.

Kedua, kuantitas dan kualitas usaha anak dalam upaya mencapai kesuksesan belajarnya. Hal ini tampak dari usaha anak untuk belajar keras, menggunakan waktu untuk belajar secara optimal, memanfaatkan waktu untuk belajar di perpustakaan, banyak membaca buku, melengkapi fasilitas belajarnya.

Ketiga, tingkat ketepatan dalam menyelesaikan tugas-tugas dari guru. Adanya motivasi positif dalam belajar, diperlihatkan anak dengan sikap senang untuk memecahkan masalah masalh yang ditugaskan kepadanya dan meningkatnya partisipasi anak dalam penyelesaian tugas-tugas kelompok. ${ }^{24}$

\section{Hasil Penelitian dan Pembahasan.}

\section{A. Penerapan Pembelajaran Saintifik pada mata pelajaran PAI di SMK Negeri}

\section{Mojoagung.}

Pembelajaran adalah proses interaksi peserta didik dengan guru dan sumber belajar pada suatu lingkungan belajar. Pembelajaran PAI merupakan pendidikan dasar dalam menerapkan nilai-nilai keislaman. Seperti dalam berperilaku, beribadah, dan bersosialisasi. ${ }^{25}$ Penerapan pembelajaran saintifik pada mata pelajaran PAI mengacu dari RPP dan silabus Kurikulum 2013. Proses pembelajaran menerapkan langkah langkah pembelajaran saintifik yang meliputi kegiatan mengamati, menanya, mecoba, menalar dan mengkomunikasikan. Kelima aktivitas ini sudah dilaksanakan melalui aktivitas kegiatan belajar siswa dikelas. Berikut ini aktifitas belajar siswa dalam pembelajaran saintifik:

1. Mengamati.

\footnotetext{
23 Abidin, Desain, 61.

24 Ibid, 139

25 Moch. Sya'roni Hasan \& Chumaidah, N. (2020, March 24). Strategi Pembelajaran PAI Anti Radikalisme di SMP Negeri 1 Ngoro Jombang. Al-Insyiroh: Jurnal Studi Keislaman, 6(1), 36-56. https://doi.org/https://doi.org/10.35309/alinsyiroh.v6i1.3815
} 
Penerapan kegiatan mengamati pada proses pembelajaran PAI muncul pada saat siswa membaca, menyimak bacaan Al-Qur'an, mengidentifikasi hukum bacaan (tajwid), dan mencermati kandungan Al-Qur' an serta mencari manfaat dan hikmah dari suatu keadaan. Aktivitas mengamati juga dilakukan siswa pada saat membaca suatu peristiwa atau gambar yang telah disajikan dibuku atau menyimak cerita atau penjelasan dari guru. Aktivitas belajar diatas sesuai dengan pendapat Fathurrahman yang menjelaskan bahwa kegiatan ketika mengamati antara lain: melihat, mengamati, membaca, mendengar dan menyimak (tanpa dan dengan alat). ${ }^{26}$

2. Menanya

Penerapan kegiatan menanya pada mata pelajaran PAI di SMK Negeri Mojoagung lebih didominasi oleh siswa dibandingkan guru. Kualitas pertanyaan mengapa dan bagaimana cukup banyak dibandingkan pertanyaan apa dan siapa. Pertanyaan timbul antara guru dengan siswa, siswa dengan guru dan siswa dengan siswa. Kegiatan ini muncul ketika siswa melakukan pengamatan, bekerja kelompok, diskusi dan presentasi. Terkadang guru harus memulai bertanya lebih dulu untuk mengetahui tingkat pengetahuan awal siswa. Hal ini sesuai teori Fathurrahman tentang aktivitas belajar ketika bertanya meliputi:

a) Mengajukan pertanyaan dari yang bersifat faktual sampai ke yang bersifat hipotesis.

b) Diawali dengan bimbingan guru sampai dengan mandiri (menjadi suatu kebiasaan). ${ }^{27}$

\section{Mencoba dan Menalar}

Penerapan kegiatan mencoba dan menalar pada mata pelajaran PAI muncul secara bersamaan pada saat siswa melakukan kegiatan diskusi. Siswa bersama temannya mencari informasi baik dari buku atau sumber lain. Siswa mencari informasi tambahan melalui kegiatan membaca di perpustakaan, dari internet, atau melakukan pengamatan langsung pada materi yang memungkinkan untuk diamati.

Kemudian siswa mendiskripsikan pengetahuan dari pengetahuan yang sudah ada dikaitkan dengan pengetahuan baru yang dia dapatkan. Saat inilah terjadi proses pembuatan kategori atau membuat hubungan data setelah itu membuat kesimpulan.Hal ini sesuai dengan pendapat Fathurrahman bahwa proses mengasosiasi meliputi kegiatan menganalisis data dalam bentuk membuat kategori atau menentukan hubungan data/

26 Muhammad Fathurrahman, Paradigma Pembelajaran Kurikulum 2013 (Yogyakarta: Kalimedia, 2015), 121.

${ }^{27}$ Fathurrahman, Paradigma, 128. 
kategori kemudian menyimpulkan dari hasil analisis data. ${ }^{28}$

4. Mengkomunikasikan

Penerapan kegiatan mengkomunikasikan pada mata pelajaran PAI muncul pada saat siswa menyajikan hasil kesimpulannya secara tertulis dibuku tugas, melakukan presentasi didepan kelas secara lisan atau melalui PPT. Hal ini sesuai dengan UU Nomor 81a Tahun 2013, yaitu mengkomunikasikan adalah menyampaikan hasil pengamatan, kesimpulan berdasarkan hasil analisis secara lisan, tertulis atau media lainnya. ${ }^{29}$

\section{B. Motivasi Belajar Siswa pada Mata Pelajaran PAI dalam Pembelajaran} Saintifik di SMK Negeri Mojoagung.

Motivasi belajar siswa pada mata pelajaran PAI di SMK tergolong tinggi. Indikator motivasi belajar siswa terlihat dari semangat dan antusias siswa dalam mengikuti kegiatan belajar mengajar, mereka selalu menampakkan rasa senang dan gembira selama mengikuti pelajaran, selalu berusaha menyelesaikan tugas dalam waktu yang ditentukan, serta besarnya rasa ingin tahu mereka yang diaplikasikan dengan melontarkan pertanyaan apabila ada materi yang kurang dipahami.Keaktifan siswa dalam mengikuti mata pelajaran PAI juga baik, karena siswa tidak pernah bolos atau mencari-cari alasan untuk keluar pada saat jam pelajaran. Tugas yang diberikan selalu dikerjakan dalam waktu yang ditentukan.

Hal ini sesuai dengan Menurut Worrell dan Stilwell yang dikutip Jamaluddin, ada 3 aspek perilaku belajar siswa yang memperlihatkan adanya motivasi positif dalam belajarnya. Pertama, adanya inisiasi aktivitas belajar anak; Kedua, kuantitas dan kualitas usaha anak dalam upaya mencapai kesuksesan belajarnya; Ketiga, tingkat ketepatan dalam menyelesaikan tugastugas dari guru. ${ }^{30}$

Siswa merasa senang dan termotivasi karena apa yang mereka butuhkan dalam belajar dan mencari ilmu sudah mereka dapatkan dengan baik dan memuaskan. Mata pelajaran PAI sangat bermanfaat bagi mereka karena menjadi bekal kehidupan. Guru dalam mengajar mendapat tanggapan yang baik dari siswa karena mampu menyajikan pembelajaran yang menarik, menyenangkan, santai tapi serius. Penanaman kedisiplinan yang diberikan guru mampu menciptakan dorongan motivasi untuk belajar.

Pembelajaran PAI sangat menyenangkan karena terdapat berbagai macam kegiatan yang dilakukan di kelas, termasuk mengamati gambar, memberi

\footnotetext{
${ }^{28}$ Fathurrahman, Paradigma, 140.

29 UU Nomor 81a Tahun 2013.

30 Jamaludin dkk , Pembelajaran Perspektif Islam (Bandung, Remaja Rosda Karya, 2015), 139.
} 
komentar, tanya jawab dengan guru, tanya jawab dengan teman, diskusi kelompok, membaca Al Qur'an, mencari hukum tajwid, merangkum, presentasi, membuat power point.

Motivasi belajar siswa terpengaruh dari dua faktor, yaitu faktor intern dan faktor ekstern. Faktor intern siswa adalah kebutuhan siswa terhadap ilmu agama yang hanya bisa didapatkan dari mengikuti mata pelajaran Pendidikan Agama dan Budi Pekerti. Faktor ektern datang dari guru dan pembelajaran. Hal ini sesuai dengan Woodworth dan Marquis yang dikutip Slameto, faktorfaktor yang mempengaruhi motivasi belajar banyak jenisnya, yang dapat digolongkan menjadi 2 jenis: Faktor Intern da Faktor Ekstern. ${ }^{31}$

C. Efektivitas pembelajaran Saintifik dalam peningkatan motivasi belajar PAI di SMK Negeri Mojoagun.

Motivasi belajar siswa terlihat dari kegiatan awal pembelajaran. Guru memberi motivasi dan memulai pembelajaran sesuai kebutuhan siswa. Kegiatan awal digunakan oleh guru untuk penumbuhan semangat siswa. Cerita dan tanya jawab yang relevan dengan materi pelajaran dilakukan guru untuk menstimulasi siswa. Guru menjelaskan tujuan pembelajaran agar siswa tahu arah tujuan belajarnya. Kegiatan awal lebih didominasi guru dengan tujuan membuat siswa senang dan menghilangkan rasa malas. Motivasi dari guru pada awal pembelajaran bersifat merangsang belajar sehingga memungkinkan siswa dapat mengikuti proses pembelajaran berikutnya dengan baik. Penjelasan tujuan belajar disampaikan agar siswa mengenal dan mengetahui tujuan akhir dari proses belajarnya.

Hal ini sesuai dengan pernyataan M. Fadhillah "Kegiatan pendahuluan pada pembelajaran saintifik implementasi kurikulum 2013 bersifat fleksibel, artinya guru dapat menyesuaikan dengan kondisi kelas masing-masing. Dalam pendahuluan yang terpenting adalah motivasi belajar dan menyampaikan tujuan pembelajaran serta memberikan stimulus mengenai materi yang akan dipelajari" ${ }^{32}$

Motivasi belajar siswa tampak dengan adanya perhatian siswa pada saat kegiatan mengamati, hal ini dikarenakan penyajian obyek pengamatan cukup menarik dan nyata. Obyek pengamatan dilengkapi dengan gambar yang mudah difahami siswa. Obyek pengamatan nyata dan menarik ini mampu mencuri perhatian siswa, siswa yang ramai, lengah atau melamun menjadi terfokus. Kegiatan mengamati merupakan kegiatan pemusatan perhatian. Guru

\footnotetext{
31 Slameto, Belajar dan Faktor-faktor yang mempengaruhinya (Jakarta:PT Rineka Cipta,2003), 30.

32 M. Fadhillah, Implementasi Kurikulum 2013 dalam pembelajaran SD/MI, SMP/MTs E SMA/MA (Yogyakarta: ARRUZZ-MEDIA, 2014), 182.
} 
menggunakan peluang ini untuk meningkatkan proses belajar pada tahap ketelitian dan kesungguhan pengamatan.

Motivasi belajar siswa tampak dari antusias dan tingginya rasa ingin tahu siswa saat kegiatan menanya. Tingginya rasa ingin tahu pada obyek yang telah di lihat, diamati atau dibaca menunjukkan daya kritis siswa meningkat, sehingga menimbulkan pertanyaan. Banyaknya pertanyaan yang diajukan menciptakan suasana pembelajaran yang semangat dan menyenangkan. Guru sebagai fasilitator menggunakan kesempatan ini untuk membangun dan mengembangkan rasa ingin tahu dan sikap kritis serta menciptakan interaksi dan komunikasi multiarah.

Motivasi belajar siswa terlihat dari kegiatan mencoba, menalar dan mengkomunikasikan. Aktivitas belajar siswa pada tiga kegiatan ini saling terkait, menjadi satu kesatuan dalam proses pembelajaran dan tidak bisa terpisah. Perwujudan motivasi belajar pada kegiatan mencoba, menalar dan mengkomunikasikan dapat dilihat dari tingginya kemauan siswa dalam melaksanakan tugas dari guru baik kelompok atau individu, seperti mencatat dalil AlQur'an / Hadist, menghafalkan, menganalisa ayat-ayat Al Qur'an, diskusi kelompok, mengerjakan tugas kelompok dan presentasi.

Selain itu tanggung jawab dan ketepatan menyelesaikan tugas menjadi ciri adanya minat dan kemauan belajarnya yang tinggi. Ketepatan dalam menyelesaian tugas menunjukkan adanya usaha keras dalam belajar dan keoptimalan siswa menggunakan dan memanfaatkan waktu untuk belajar. Guru fasilitator menggunakan kesempatan ini untuk melatih siswa jujur, teliti disiplin, taat aturan, kerja keras, toleransi, berani berpendapat.

Berdasarkan indikator motivasi belajar siswa yang tampak pada setiap aktifitas belajar dari kegiatan mengamati, menanya, menalar, mengasosiasi dan mengkomunikasikan, menunjukkan dua unsur efektifitas pembelajaran yang dilihat dari sudut pandang sumber yang berbeda:

1. Menurut PP nomor 19 tahun 2005 tentang standar nasional pendidikan menjelaskan bahwa suasana pembelajaran yang efektif yaitu suasana belajar yang interaktif, inspiratif, menyenangkan, menantang, inovatif dan menemukan sendiri. ${ }^{33}$ Interaktif karena siswa sangat aktif dalam bertanya, menjawab, berkomentar, berpendapat dan mengerjakan tugas., Inspiratif karena siswa semangat dan termotivasi untuk belajar mata pelajaran PAI. Menyenangkan karena siswa merasa senang mengikuti proses pembelajaran baik karena faktor intern atau ekstern. Menantang karena siswa berusaha

33 Sofan Amri, Pengembangan dan Model Pembelajaran dalam Kurikulum 2013 (Jakarta: Prestasi Pustaka Raya, 2015), 199. 
keras dalam belajar dan menyelesaikan tugas. Inovatif karena aktifitas belajar siswa bermacam-macam. Menemukan sendiri karena siswa secara aktif dapat mengkonstruksi konsep, hukum atau prinsip melalui tahapan-tahapan mengamati, merumuskan masalah, mengajukan atau merumuskan hipotesis, mengumpulkan data dengan berbagai teknik, menganalisis data, menarik kesimpulan dan mengomunikasikan konsep, hukum yang di temukan.

2. Pembelajaran ini mampu membangkitkan proses belajar siswa karena siswa termotivasi dengan kegiatan dan aktifitas belajar yang dia lakukan. Guru senantiasa menumbuhkan kompetensi siswa dengan cara menyajikan obyek pengamatan melalui media yang menarik,menstimulasi pertanyaan, memberi kesempatan bertanya yang lebih banyak, memberi tugas individu atau kelompok.. Aktifitas belajar siswa dan mengajar guru menumbuhkan dan mengembangkan kompetensi siswa seperti kesungguhan, ketelitian, kritis, kreativitas, rasa ingin tahu, jujur, teliti disiplin, taat aturan, kerja keras, toleransi, berani berpendapat. Sebagaimana yang dikatakan oleh Fathurrahman bahwa: suatu proses belajar mengajar dikatakan baik atau efektif, jika kegiatan belajar mengajar tersebut dapat membangkitkan proses belajar. Pembelajaran yang memiliki motivasi tinggi di tunjang dengan pengajar yang mampu memfasilitasi motivasi tersebut akan membawa pada keberhasilan pencapaian target belajar. ${ }^{34}$

D.Faktor pendukung dan penghambat efektifitas pembelajaran saintifik dalam peningkatan motivasi belajar PAI.

1.Faktor Pendukung

a. Guru. Guru di SMK Negeri Mojoagung mempunyai semangat dan tanggung jawab tinggi dalam menerapkan pembelajaran saintifik. Guru berusaha maksimal untuk meningkatkan kualitas pembelajaran, melakukan penilaian dan memanfaatkan peluang untuk meningkatkan kompetensi siswa. Dibarengi dukungan yang besar dari pihak sekolah dalam meningkatkan kualitas guru, menghasilkan kualitas pembelajaran semakin baik dan efektif. Kualitas pembelajaran guru yang baik, mampu memberi pengaruh yang positif bagi siswa.

b. Disiplin sekolah. Peraturan akademik sekolah yang menjadikan mata pelajaran PAI wajib diikuti dan menentukan kenaikan kelas. Hal ini mampu menjadi awal mula terbentuknya motivasi siswa untuk mengikuti mata pelajaran ini. Kedisiplinan dan sistem penilaian proses yang dilakukan guru menjadikan siswa termotivasi untuk terlibat aktif dalam proses pembelajaran sehingga pembelajaran menjadi efektif.

\footnotetext{
${ }^{34}$ Fathurrahman, Paradigma, 26.
} 
c. Sarana prasarana. Sarana prasarana di SMK Negeri Mojoagung seperti perpustakaan, WIFI, ruang kelas yang nyaman dengan fasilitas lengkap menjadi faktor pendukung efektifitas pembelajaran saintifik di sekolah ini.

2. Faktor penghambat.

a. Waktu belajar. Waktu belajar yang terlalu siang atau setelah kegiatan olah raga menjadi faktor penghambat keefektifan pembelajaran saintifik ini. Hal ini menyebabkan kondisi siswa yang lemah, letih dan lesu sehingga pembelajaran saintifik menjadi kurang efektif.

b. Media pembelajaran, minimnya media pembelajaran seperti peralatan jenazah dan media lainnya menjadi penghambat efektifitas pembelajaran.

Hal ini sesuai dengan Thursan Hakim bahwa faktor eksternal yang mempengaruhi keberhasilan pembelajaran ada 2, yaitu eksternal lingkungan sosial dan nonsosial. ${ }^{35}$

\section{Kesimpulan}

Pembelajaran saintifik pada mata pelajaran PAI di SMK N Mojoagung diterapkan melalui aktivitas belajar siswa sebagai berikut: Mengamati (melihat gambar, membaca, mendengarkan dan mengidentifikasi bacaan Al-Qur'an, menyimak penjelasan, mencermati manfaat dan hikmah), menanya (guru bertanya kepada siswa, siswa bertanya kepada guru, siswa bertanya pada siswa), mencoba (menghafal dalil Al-Qur'an, mencari manfaat dan hikmah, menggali informasi tentang akibat dari suatu perbuatan, mencari dalil Al-Qur'an atau hadist dari sumber lain), menalar (membuat kesimpulan manfaat dan hikmah dari perintah atau larangan, membuat kesimpulan hal-hal yang yang berkaitan dengan dampak dari melakukan suatu perbuatan), mengkomunikasikan (mengutarakan pendapat, menyajikan hasil kesimpulan secara lisan atau tertulis dan menanggap ipresentasi temannya).

Motivasi belajar siswa pada mata pelajaran PAI tergolong tinggi karena terpengaruh oleh faktor intern berupa kebutuhan siswa terhadap ilmu agama dan ekstern yaitu guru dan pembelajaran. Pembelajaran saintifik efektif dalam meningkatkan motivasi belajar PAI karena langkah langkah pembelajaran yang menumbuhkan motivasi dan kompetensi siswaberupakesungguhan, ketelitian, kritis, kreatif, rasa ingin tahu,jujur, teliti, disiplin, taat aturan, kerja keras, toleransi dan berani berpendapat.Faktor pendukung adalah guru, disiplin sekolahdan sarana prasarana.Faktor penghambatnya adalah jam siang atau setelah olah raga dan minimnya media pembelajaran. Kedua faktor diatas berasal dari faktor eksternal lingkungan sekolah.

${ }^{35}$ Jamaluddin, Pembelajaran Perspektif Islam (Bandung: Remaja Rosda Karya, 2015), 147. 


\section{Daftar Pustaka}

Abidin,Yunus. Desain Sistem Pembelajaran dalam Konteks Kurikulum 2013 (Bandung: Refika Aditama, 2014

Amri, Sofan. Pengembangan dan Model Pembelajaran dalam Kurikulum 2013. Jakarta: Prestasi Pustaka Raya, 2015.

Azis, Abdul. Orientasi Sistem Pendidikan Agama di Sekolah. Yogyakarta: Teras, 2010.

Daryanto, Pendekatan Pembelajaran Saintifik Kurikulum 2013. Yogyakarta: Gava Media,2014.

Fadhillah, M. Implementasi Kurikulum 2013 dalam pembelajaran SD/MI, SMP/MTs $\mathcal{E}$ SMA/MA (Yogyakarta: ARRUZZ-MEDIA, 2014), 182.

Fathurrahman, Muhammad Paradigma Pembelajaran Kurikulum 2013. Yogyakarta: Kalimedia, 2015

Hasan, M., \& Chumaidah, N. (2020, March 24). Strategi Pembelajaran PAI Anti Radikalisme di SMP Negeri 1 Ngoro Jombang. Al-Insyiroh: Jurnal Studi Keislaman, 6(1), 36-56. https://doi.org/https://doi.org/10.35309/alinsyiroh.v6i1.3815

Hasan, Moch. Sya'roni, and Dian Eka Saputri. 2020. "Pembelajaran PAI Berbasis Moving Class Di SMP Negeri 1 Gudo Jombang". Attaqwa: Jurnal Ilmu Pendidikan Islam 16 (2):113-25. https:/ / doi.org/10.36835/attaqwa.v16i2.47.

Hasan, Moch. 2019. "INTERNALISASI NILAI TOLERANSI BERAGAMA". DAR EL-ILMI : Jurnal Studi Keagamaan, Pendidikan Dan Humaniora 6 (1), 79-111. http://e-jurnal.unisda.ac.id/index.php/dar/article/view/1469.

Hidayat, Sholeh. Pengembangan Kurikulum Baru. Bandung: Remaja Rosda Karya, 2013

Jamaluddin, Pembelajaran Perspektif Islam. Bandung: Remaja Rosda Karya, 2015.

Jamaludin dkk, Pembelajaran Perspektif Islam (Bandung, Remaja Rosda Karya, 2015), 139.

Mulyasa, H.E. Pengembangan dan Implementasi Kurikulum 2013. Bandung: Remaja Rosda Karya, 2015..

Sani, Ridwan Abdulloh Pembelajaran Saintifik untuk Implementasi Kurikulum 2013. Jakarta: Bumi Aksara, 2014.

Slameto, Belajar dan Faktor-faktor yang mempengaruhinya. Jakarta:PT Rineka Cipta, 2003 